\title{
Metabolic and Hormonal Investigations in Long-term Streptozotocin Diabetic Rats on Different Dietary Regimens
}

\author{
F. H. Schmidt, E. G. Siegel ${ }^{1}$, and V. E. Trapp \\ Boehringer Mannheim GmbH, Metabolic Research Division, Mannheim, FRG
}

\begin{abstract}
Summary. Groups of diabetic rats $(65 \mathrm{mg} / \mathrm{kg}$ streptozotocin SC) were fed ad lib on three different dietary regimens for 43 weeks: a standard control diet (68\% of calories as carbohydrate, $20 \%$ as protein, and $12 \%$ as fat), a low carbohydrate high protein diet (6\% carbohydrate, $63 \%$ protein, $31 \%$ fat) or a low carbohydrate-high fat diet (5\% carbohydrate, $75 \%$ fat, $20 \%$ protein). The high fat diet resulted in a fall of blood glucose from 700 to $350 \mathrm{mg} / 100 \mathrm{ml}$. Rats fed the high protein diet showed a similar initial decrease in blood glucose concentration, and a further improvement was evident from the 28th week on. After 43 weeks blood glucose levels were below $180 \mathrm{mg} / 100 \mathrm{ml}$ and glycosuria below $100 \mathrm{mg} / 24 \mathrm{~h}$ in all rats fed the high protein diet. When rats exhibiting blood glucose levels below $180 \mathrm{mg} / \mathrm{dl}$ were transferred temporarily to standard diet blood glucose levels increased and marked glycosuria was observed. Rats on the standard diet maintained blood glucose concentrations greater than $500 \mathrm{mg} / 100 \mathrm{ml}$ and glycosuria of about $16 \mathrm{~g} / 24 \mathrm{~h}$ throughout the experiment. The pancreatic insulin content at death of rats fed the standard diet or the high fat diet was $1 \%$ of normal rats, whereas the values for the rats on the high protein diet were increased to $9 \%$. Animals fed the low carbohydrate diets showed greater weight gain. In the high fat diet group there was a marked rise after 43 weeks in plasma triglycerides, free fatty acids, 3-hydroxybutyrate and acetoacetate in the plasma. Urea excretion was raised in the animals on the high protein diet. Thus, treatment with low carbohydrate diets for 10 months regardless of fat and protein content markedly improved the diabetic state of rats.
\end{abstract}

\footnotetext{
1 Present address: Institut de Biochimie Clinique, Sentier de la Roseraie, CH-1211 Geneva 4, Switzerland
}

Key words: Streptozotocin diabetes, rats, low carbohydrate-high protein diet, low carbohydrate-high fat diet, blood glucose, urinary glucose, serum lipids, ketone bodies, serum insulin, pancreatic insulin, pancreatic glucagon.

Since the introduction of diabetogenic substances for producing experimental diabetes in animals, numerous investigations have been carried out to determine the site of action, the organ toxicity, and the metabolic response to these agents [for review see 2 , 3]. There are, however, only a few long-term studies in rats without insulin substitution incorporating studies of diabetes-induced metabolic and morphological changes [4-7]. There are even fewer studies on the long term effects of dietary modifications on intermediary metabolism in diabetic rats [5-7]. The majority of these studies are based on relatively short periods of observation. One reason for this is that the death rate is high because of the severity of the diabetes, with animals dying before secondary changes can be seen. The present study was designed to maintain diabetic rats over a longterm period and to investigate the effects of carbohydrate restriction on metabolic parameters and organ changes. A preliminary account of these observations has been published [1].

\section{Materials and Methods}

Experimental Animals, Maintenance and Feeding

Male Sprague-Dawley rats aged approximately 100 days with a mean weight of $315 \mathrm{~g}$ (range $280-340 \mathrm{~g}$ ) were used. Diabetes was produced by injecting a freshly prepared solution ( $\mathrm{pH}$ 6) of strep- 
Table 1. Composition of diets

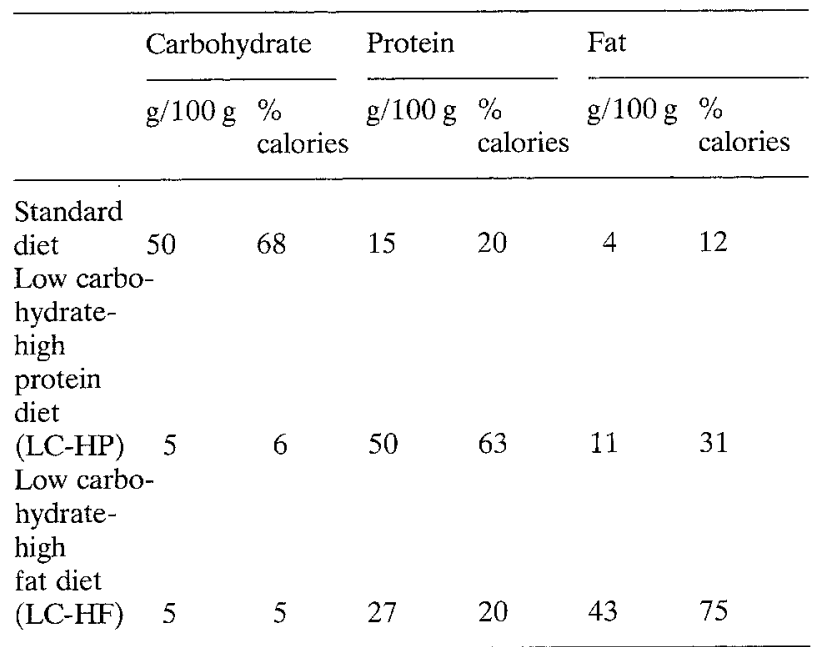

$\%$ calories calculated on the basis of $4.1 \mathrm{kcal} / \mathrm{g}$ for carbohydrate, $4.1 \mathrm{kcal} / \mathrm{g}$ protein and $9.1 \mathrm{kcal} / \mathrm{g}$ fat

tozotocin $(65 \mathrm{mg} / \mathrm{kg}) \mathrm{SC}$ in the nape of the neck. Groups of 5 animals were kept in wire cages in an air-conditioned room. Food and water were supplied ad lib. In order to obtain urine the animals were placed singly for $24 \mathrm{~h}$ in metabolic cages with food racks. A total of 152 rats were made diabetic. Of these, 142 had blood glucose values of more than $420 \mathrm{mg} / 100 \mathrm{ml}$ after one week; none had died. Only rats with a minimum weight of $280 \mathrm{~g}$ after one week were used for the further experiments. Eleven days after the streptozotocin injection, the animals were divided into groups by means of random numbers. From this time onwards the animals were fed either on a low carbohydrate-high protein diet (LC-HP group), a low carbohydrate-high fat diet (LC-HF group) or a standard diet (control group). The high fat diet consisted solely of linseed previously soaked in water. The composition of the food is shown in Table 1. After 43 weeks of diabetes 14 control animals, 11 of the LC-HP group and 14 of the LC-HF group were chosen randomly, killed by cervical dislocation in the fed state between $1000 \mathrm{~h}$ and $1400 \mathrm{~h}$ and immediately bled. Eight non-diabetic male Sprague-Dawley rats kept under the same conditions (standard food) were killed at the same time. The age of these animals was slightly less than that of the diabetic animals (10 months vs. 13 months). Their mean weight was $517 \pm 7 \mathrm{~g}$, range $470-540 \mathrm{~g}$.

\section{Analytical Methods}

Each 2-3 weeks tail vein blood samples were taken in the nonfasting state between $0900 \mathrm{~h}$ and $1100 \mathrm{~h}$. Blood glucose was determined in $10 \mu \mathrm{l}$ of haemolysed blood [8], triglycerides [9] and 3-hydroxybutyrate [10] were measured by enzymatic methods. Determinations of 3-hydroxybutyrate were performed in $20 \mu \mathrm{l}$ plasma samples without deproteinisation directly after blood withdrawal. Twenty-four hour urinary glucose excretion was determined enzymatically [8], the urea concentration in the urine by Fawcett's method [11] and ketonuria semiquantitatively by means of test-strips (Ketur-Test ${ }^{\circledR}$, Boehringer Mannheim $\mathrm{GmbH}$ ). After sacrifice blood gas analysis was carried out within $30 \mathrm{~min}$ in the mixed blood of the individual animals [12]. The following additional parameters were determined in plasma: cholesterol [13], acetoacetate [14], free fatty acids [15], free glycerol [15] and plasma insulin. Plasma not used immediately was stored at $-20^{\circ}$. The insulin and glucagon content of the pancreas were determined after extraction in acid ethanol $(750: 235: 15$ by volume of ethanol: water: concentrated $\mathrm{HCl}$ ). Immunoreactive insulin was determined by radioimmunoassay [16] using a rat standard. Glucagon was determined by radioimmunoassay using Dr. Unger's antibody $30 \mathrm{~K}[17]$.

\section{Statistics}

Graphs were plotted showing the means and standard errors of the mean (SEM). Normal linear distribution could not be demonstrated for any of the parameters determined throughout the course of the experiment. Blood and urinary glucose and the serum triglycerides gave an approximately log-normal distribution. Therefore, comparison was carried out using the Wilcoxon-MannWhitney test (U-test) [18].

\section{Results}

\section{Body Weight, General Condition}

As expected [3] body weight (Fig. 1) decreased during the first 8 days after streptozotocin injection in all groups, from values of about 320 to $300 \mathrm{~g}$. The control group on standard diet remained more or less constantly at this weight throughout the 10 months of the experiment. The mean weight of animals in the LC-HF group during the 5 th week was $270 \mathrm{~g}$. This fall could probably be attributed to the extreme change in the diet. Only after the 16th week were they heavier than at the beginning, but by the end of the experiment they had reached $380 \mathrm{~g}$. The LC-HP rats exhibited a clear weight gain which was, however, somewhat less than that of non-diabetic animals (when compared to non-diabetic controls, see Methods). Between the 40th and the 43rd week many animals (in all three diabetic groups) developed rhinitis, bronchitis and keratitis. Rats of the LC-HP group were most affected. The illness caused a fall in weight, whereas other parameters, such as blood glucose concentration and glucose excretion did not change. The signs of infection had improved in most of the animals by the time they were killed. Only animals that had shown some regain in weight were included in the post mortem evaluation.

The condition of the coat can be taken as an approximate indicator of the general condition of laboratory rats [19]. In animals of the LC-HP and LC-HF diet treated groups it was considerably smoother than in the control group on standard diet; the grooming behaviour of the latter was also less marked. In the LC-HP group, a total of 6 out of the 20 animals died by the 40th week. In the control group there was only one death; none had died in the LC-HF group. Two animals had renal tumours, two animals had tumours of the nape of the neck and in 

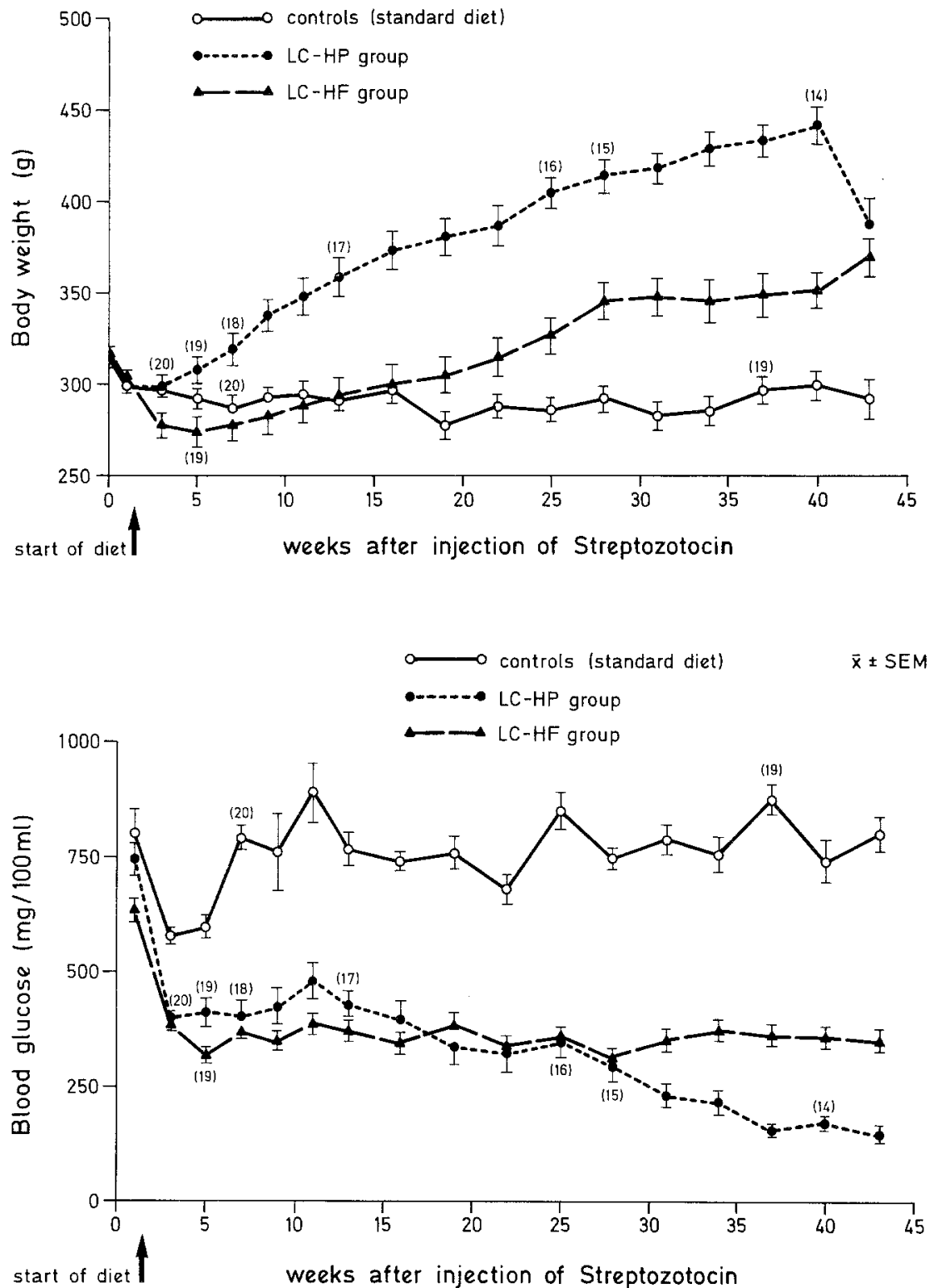

Fig. 1. Effects of different diets on weight in diabetic rats. The different dietary regimens were begun 11 days after the injection of streptozotocin: 20 rats were fed on a standard diet, 20 on low carbohydrate-high protein (LC-HP) diet and 19 on low carbohydrate-high fat (LC-HF) diet. Changes in the number of animals due to death are indicated in parentheses above the corresponding curve at the week they occurred. Values are shown as mean \pm SEM. For the composition of the diets, see Table 1

Fig. 2. Blood glucose of diabetic rats fed on different diets. Values given as mean \pm SEM are shown in the non-fasting state. Changes in the number within groups are indicated above the curves in parentheses (see also Figure 1). Animals were distributed to the different dietary regimens according to random numbers 11 days after streptozotocin injection two further animals renal tumours were found at the end of the experiment.

\section{Blood and Urinary Glucose}

Figures 2 and 3 show the changes in blood and urinary glucose. The injection of streptozotocin resulted in blood glucose levels between 500 and $900 \mathrm{mg} /$ $100 \mathrm{ml}$ and urinary glucose excretions of $10-16 \mathrm{~g} /$ $24 \mathrm{~h}$. In animals on the standard diet, no improvement of the diabetic state could be seen. The fat-rich diet produced a fall in blood glucose to values around $350 \mathrm{mg} / 100 \mathrm{ml}$ and urinary glucose excretions around $1 \mathrm{~g} / 24 \mathrm{~h}$. No further improvement occurred. In the LC-HP group there was a similar initial improvement of the blood glucose, so that up to the 28 th week the blood glucose levels were similar for the 2 groups. Thereafter, however, the LC-HP group demonstrated a further fall. After 43 weeks blood glucose levels were less than $180 \mathrm{mg} / 100 \mathrm{ml}$ and the excretion of glucose in the urine less than $100 \mathrm{mg} /$ $24 \mathrm{~h}$ for every single animal. In the control group none of the animals showed blood glucose values below $400 \mathrm{mg} / 100 \mathrm{ml}$ during the whole of the experimental period of 10 months.

The 24 hour urinary volumes were fairly constant 


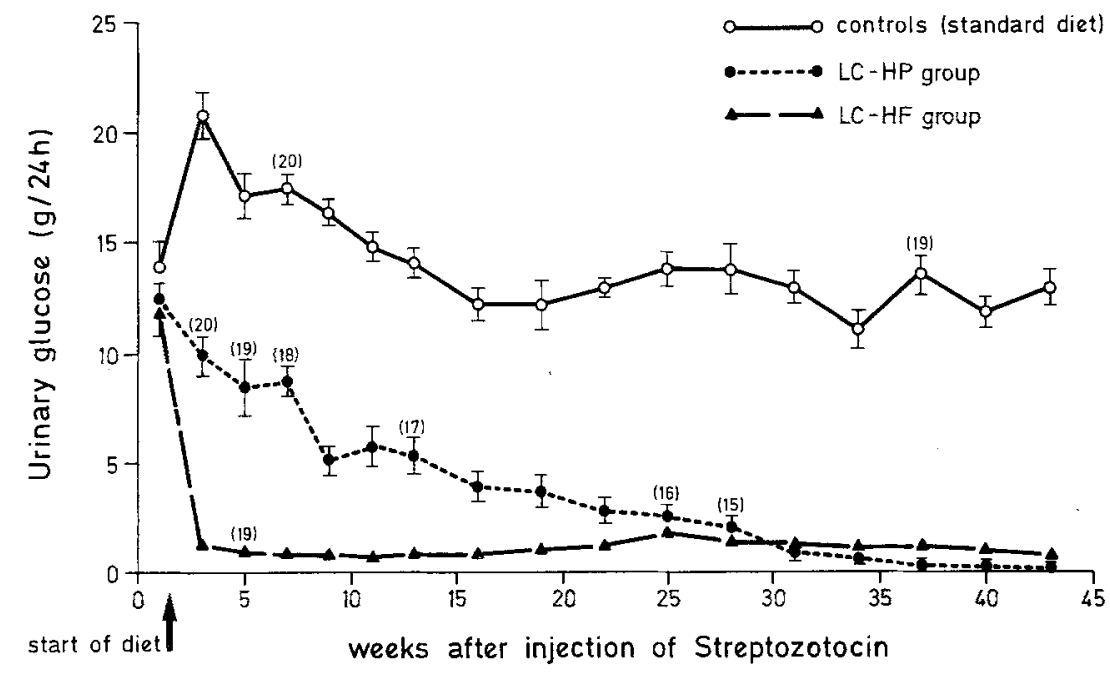

Fig. 3. Excretion of glucose in the urine. Values are given as mean \pm SEM. If the SEM was smaller than the symbol used, the SEM was omitted. See Figure 1 for other details
Table 2. Food intake in the 40 th week in diabetic rats fed different diets

Diabetic controls LC-HP group LC-HF group [11]

[6]

[4]

Food intake

(kcal/24 h)

Food intake minus

$84 \pm 5$

$46 \pm 3$

$42 \pm 3$

energy lost as

urinary glucose

(kcal/24 h)

$36 \pm 2$

$36 \pm 3$

$30 \pm 3$

Food intake and urinary glucose excretion were determined in the fortieth week. The lower line shows the estimated "retained" calories. Values are given as mean \pm SEM. Numbers of observations in parentheses

Table 3. Insulin and glucagon determinations after 43 weeks diabetes in rats fed different diets

\begin{tabular}{lllll}
\hline & $\begin{array}{l}\text { Non-diabetic } \\
\text { controls } \\
{[8]}\end{array}$ & $\begin{array}{l}\text { Diabetic } \\
\text { controls } \\
{[14]}\end{array}$ & $\begin{array}{l}\text { LC-HP } \\
\text { group } \\
{[10]}\end{array}$ & $\begin{array}{l}\text { LC-HF } \\
\text { group } \\
{[12]}\end{array}$ \\
\hline $\begin{array}{l}\text { Serum insulin } \\
\text { ng/ml }\end{array}$ & $1.21 \pm 0.21$ & $0.38 \pm 0.04$ & $0.37 \pm 0.05$ & $0.43 \pm 0.05$ \\
$\begin{array}{l}\text { Pancreatic } \\
\text { insulin } \\
\text { content } \\
\text { (ng/mg) }\end{array}$ & $98.7 \pm 9.0$ & $1.3 \pm 0.15$ & $8.8 \pm 0.9$ & $1.3 \pm 0.3$ \\
$\begin{array}{l}\text { Pancreatic } \\
\text { glucagon } \\
\text { content } \\
\text { (ng/ml) }\end{array}$ & $3.8 \pm 0.3$ & $3.2 \pm 0.3$ & $2.8 \pm 0.3$ & $3.9 \pm 0.6$ \\
\hline
\end{tabular}

Insulin and glucagon were determined at death 43 weeks after streptozotocin injection. Non-diabetic controls in included. Values are given as mean \pm SEM. Number of observations in parentheses from the fifth week onwards, being 200 to $300 \mathrm{ml}$ in the diabetic controls, 20 to $30 \mathrm{ml}$ in the LC-HF group and 60 to $90 \mathrm{ml}$ in the LC-HP group, in spite of the decrease in urinary glucose excretion.

In the 25th week those animals in the diet treated groups (five LC-HP and two LC-HF) that showed blood glucose values below $180 \mathrm{mg} / 100 \mathrm{ml}(102$ to $154 \mathrm{mg} / 100 \mathrm{ml}$; urine glucose $<0.1 \mathrm{~g} / 24 \mathrm{~h}$ ) were transferred temporarily for 3 days to the carbohydrate-rich standard diet. All responded with a rise in blood glucose to $238-386 \mathrm{mg} / 100 \mathrm{ml}$ and glycosuria ( 0.6 to $4.1 \mathrm{~g} / 24 \mathrm{~h}$ ); they could thus be classified as still being diabetic. After refeeding with low carbohydrate diets, blood glucose and urinary glucose excretion returned to previous values.

\section{Food Intake}

The caloric content of the various types of food was calculated from the combustion values for carbohydrate $(4.1 \mathrm{kcal} / \mathrm{g})$, neutral fats $(9.3 \mathrm{kcal} / \mathrm{g})$, and proteins $(4.1 \mathrm{kcal} / \mathrm{g})$. The untreated diabetic animals ingested more than twice as many calories as the diettreated animals (Table 2). However, animals fed on the standard diet lost considerably more energy in the form of urinary glucose. Compared to this, loss of other energy-rich substrates (e. g. ketone bodies) was small and was therefore not taken into account. After subtracting the calories lost due to urinary glucose excretion the diabetic control rats and the rats fed on protein-rich diet were found to retain about $36 \mathrm{kcal} /$ day. Because the animals fed on the high fat diet scattered their food (linseed) considerably, only 4 of them could be used in the evaluation. After subtrac- 


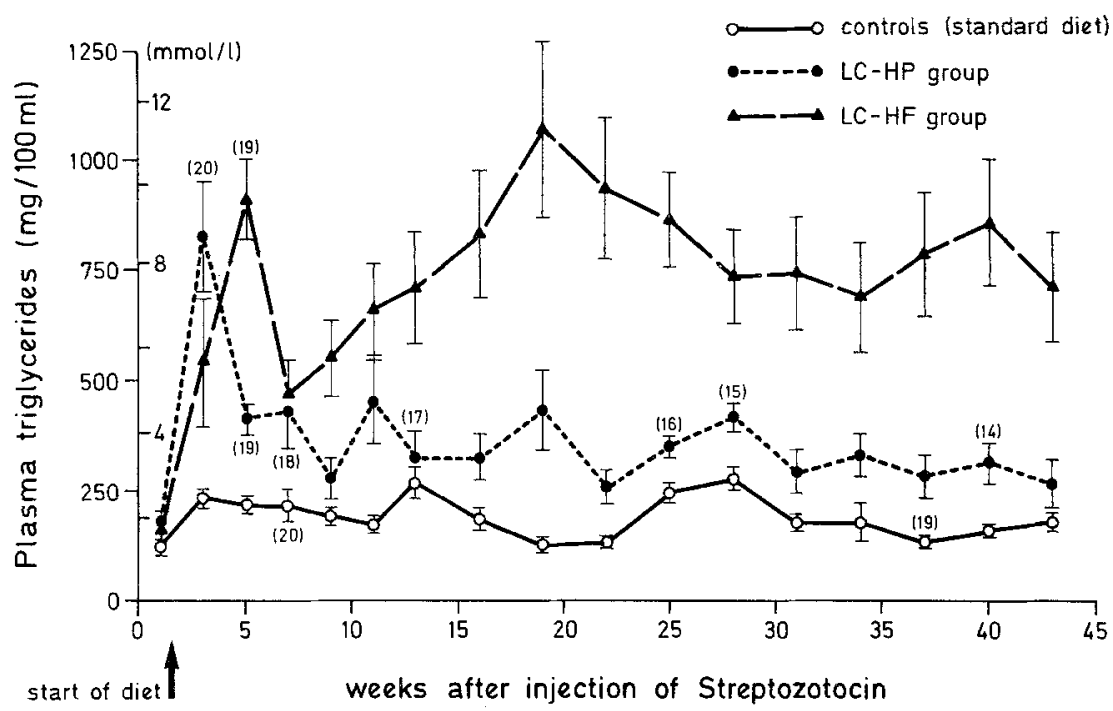

Fig. 4. Plasma triglyceride levels of diabetic rats fed on different diets. Values given as mean \pm SEM are shown in the non-fasting state. Changes in the number of rats are indicated as described in Figure 1

tion of the energy lost as urinary glucose no significant difference was noted between diabetic controls and the LC-HF group.

\section{Insulin and Glucagon}

There was no significant difference between the serum insulin concentrations of the different diabetic groups at death (Table 3 ). They were, however, significantly lower than in non-diabetic animals $(p<$ 0.001 ). The insulin content of the pancreas was reduced to $1.3 \%$ in the diabetic controls fed on standard diet when compared to non-diabetic rats. A significantly higher value was found in the LC-HP group than in either the LC-HF group or the diabetic controls $(\mathrm{p}<0.001)$. The mean content of the LCHP group was, however, still only about $9 \%$ of the normal pancreatic insulin content of non-diabetic controls $(\mathrm{p}<0.001)$. The LC-HF group did not differ significantly from the diabetic control group. The determination of the glucagon content of the pancreas did not show any significant difference between the groups or any difference from non-diabetic controls. The concentrations were between 3 and $4 \mathrm{ng} /$ mg pancreatic tissue.

\section{Excretion of Urea in the Urine}

Twenty-four hour urea excretion measured in the 25 th week was $1.31 \pm 0.15 \mathrm{~g} / 24 \mathrm{~h}(\mathrm{n}=20)$ in diabetic control rats on the standard diet. In the LC-HP group it was $2.38 \pm 0.16(\mathrm{n}=15)$ and in the LC-HF group $0.60 \pm 0.08 \mathrm{~g} / 24 \mathrm{~h}$. The former was significantly increased compared to rats on the standard diet $(\mathrm{p}<0.001)$ and the latter significantly decreased $(\mathrm{p}<0.001)$.

\section{Plasma Triglycerides, Cholesterol, Ketone Bodies, Free Glycerol and Free Fatty Acids}

Figure 4 shows the plasma triglyceride levels of the rats during 10 months. The LC-HF animals had high non-fasting plasma triglyceride levels compared with the mild hypertriglyceridaemia of the controls (compare Table 4). At the same time the LC-HF group exhibited marked ketonuria, which diminished slightly during the course of the experiment. In contrast, ketonuria was not detected in the diabetic control animals. In the group treated with the LC-HP diet there was initially a marked hypertriglyceridaemia similar to that of the LC-HF group, but by the 9 th week this had fallen to levels only moderately greater than those of the diabetic controls. An initially marked ketonuria parallelling the high triglyceride levels diminished continuously and had disappeared by the 16 th week.

Table 4 shows that the triglyceride, 3-hydroxybutyrate and acetoacetate levels in the plasma of diabetic controls were slightly raised $(\mathrm{p}<0.05)$ in comparison with the non-diabetic animals. In the LC-HF group, these parameters were considerably higher, as well as the concentration of free glycerol $(\mathrm{p}<0.025)$ and free fatty acids $(\mathrm{p}<0.001)$, when compared to diabetic controls fed on standard diet. The markedly raised 3-hydroxybutyrate and acetoacetate concentrations $(\mathrm{p}<0.001)$ are particularly striking. The acetoacetate and 3-hydroxybutyrate levels in the LC-HP group did not differ significantly 
Table 4. Plasma ketone bodies, triglycerides, cholesterol, free fatty acids, and free glycerol after 43 weeks diabetes

\begin{tabular}{lllll}
\hline & $\begin{array}{l}\text { Non-diabetic Diabetic } \\
\text { controls } \\
{[8]}\end{array}$ & $\begin{array}{l}\text { controls } \\
{[14]}\end{array}$ & $\begin{array}{l}\text { LC-HP } \\
\text { group } \\
{[10]}\end{array}$ & $\begin{array}{l}\text { LC-HF } \\
\text { group } \\
{[12]}\end{array}$ \\
\hline $\begin{array}{l}\text { Acetoacetate } \\
\text { (mmol/1) }\end{array}$ & $0.03 \pm 0.002$ & $0.09 \pm 0.01$ & $0.06 \pm 0.01$ & $0.30 \pm 0.09$ \\
$\begin{array}{l}\text { 3-Hydroxy- } \\
\text { butyrate } \\
\text { (mmol/1) }\end{array}$ & $0.12 \pm 0.02$ & $0.20 \pm 0.03$ & $0.15 \pm 0.02$ & $1.35 \pm 0.38$ \\
$\begin{array}{l}\text { Triglycerides } \\
\text { (mmol/l) }\end{array}$ & $1.24 \pm 0.07$ & $1.97 \pm 0.38$ & $2.85 \pm 0.65$ & $5.11 \pm 1.14$ \\
$\begin{array}{l}\text { Free glycerol } \\
\text { (mmol/1) }\end{array}$ & $0.11 \pm 0.02$ & $0.10 \pm 0.03$ & $0.09 \pm 0.02$ & $0.14 \pm 0.01$ \\
$\begin{array}{l}\text { Free fatty } \\
\text { acids } \\
\text { (mmol/1) }\end{array}$ & $0.25 \pm 0.12$ & $0.24 \pm 0.07$ & $0.25 \pm 0.07$ & $0.46 \pm 0.07$ \\
$\begin{array}{l}\text { Cholesterol } \\
\text { (mmol/1) }\end{array}$ & $2.52 \pm 0.20$ & $3.37 \pm 0.67$ & $8.59 \pm 0.80$ & $4.40 \pm 0.65$ \\
\hline
\end{tabular}

The plasma lipid metabolites were determined immediately postmortem 43 weeks after streptozotocin. Non-diabetic controls are included. Values are given \pm SEM. Numbers of animals shown in parentheses

from those of the diabetic controls $(\mathrm{p}>0.05)$. The elevation of the plasma cholesterol, on the other hand, was highly significant $(\mathrm{p}<0.001)$, whereas no significant difference was seen between the LC-HF group and diabetic controls. The slightly lower cholesterol level of the non-diabetic controls was not significantly different from the diabetic controls.

The blood gas analysis showed absence of acidosis ( $\mathrm{pH}$ between 7.3 and 7.4) and the standard bicarbonate was normal in all the groups (values between 21 and $27 \mathrm{mEq} / \mathrm{l}$ ).

\section{Discussion}

These experiments demonstrate that rats with severe streptozotocin diabetes can be kept alive with good care in air conditioned surroundings for almost one year without any insulin substitution. Figures 2 and 3 show how markedly blood and urine glucose levels can be influenced by dietary means alone, even in severe streptozotocin diabetes. The initial decrease of the blood glucose in response to the two diets and the time course until the 25th week show that approximately as good a metabolic control may be achieved by a diet very low in carbohydrate and high in protein content $(6 \%$ and $63 \%$ of calories respectively) as by a low carbohydrate-high fat diet (5\% $\mathrm{CHO}, 75 \%$ fat). It appears, therefore, that the possible conversion into glucose of the substituting substrate is less important than the reduction of dietary carbohydrate itself. It is interesting to note in this context that a similar decrease of blood and urinary glucose has been observed when the carbohydrate content was reduced only to $27 \%$ [20]. A reduction of the glycosuria from 5 to $1 \mathrm{~g} / 24 \mathrm{~h}$ with a diet containing $30 \%$ fat and little carbohydrate was demonstrated in 1951 for alloxan-diabetic rats [7]. Other authors [6] were able to demonstrate a reduction from 27 to $0.5 \mathrm{~g} / 24 \mathrm{~h}$ with a diet containing $30 \%$ fat but also $60 \%$ carbohydrate. With a diet that was protein enriched and only slightly reduced in carbohydrate there was a reduction of the glucose excretion by half $[5,7]$.

The urine volumes of rats fed on the LC-HP diet remained considerably above normal even at the end of the experiment when the glucose excretion was minimal. One possible explanation for this unexpected finding could be the higher than normal excretion of urea. Possibly, this increased diuresis, which is about 10 times that of normal animals, could explain to some extent the higher glucose excretion of the LC-HP group up to the 20th week, compared with the LC-HF group, in the face of similar blood glucose levels. In support of this hypothesis is the finding in humans of a rise in physiological glycosuria during urea diuresis [21].

The immediate effects of the low carbohydrate diets are clearly demonstrated by the initial decrease of the blood glucose levels. An additional improvement of the LC-HP group, evident from the 28th week, (Fig. 2) led to blood glucose values below $180 \mathrm{mg} / 100 \mathrm{ml}$ and glycosuria below $100 \mathrm{mg} / 24 \mathrm{~h}$ by the $43 \mathrm{rd}$ week in all the animals fed on this diet. The serum insulin determinations carried out post mortem did not explain this, since no statistical difference between the groups was found. By contrast, the insulin content in the pancreas of the different groups (standard, LC-HF and LC-HP diet) was 1\%, 1\% and $9 \%$, respectively, of the insulin content of non-diabetic pancreases. In a systematic study, Junod et al. [22] found $2 \%$ compared to non-diabetic pancreases, when $65 \mathrm{mg} / \mathrm{kg}$ streptozotocin IV was injected and $9 \%$ with a dose of $45 \mathrm{mg} / \mathrm{kg}$. These rats with $9 \%$ pancreatic insulin content, fed on a standard diet, were clearly diabetic. This was also demonstrated in the present study since the rats showing blood glucose levels below $180 \mathrm{mg} / 100 \mathrm{ml}$ reverted to higher plasma glucose concentrations and demonstrated considerably glycosuria when they were fed on the standard diet for 3 days. This metabolic behaviour demonstrates, however, that under certain conditions of insulin deficiency high blood glucose levels can be avoided by reduction of the carbohydrate intake.

The protein-rich diet thus appears to have a favourable effect on the recovery of the diabetic pancreas. It is unlikely that it is only the reduction of glycaemia that causes pancreatic insulin content to rise, since the animals on the LC-HF diet, exhibiting similar blood glucose levels up to the 28 th week, did not show such pancreatic recovery. It may be of 
interest that in an additional experiment diabetic rats, having been fed on standard diet and having been transferred to this LC-HP diet after $3^{1 / 2}$ months of severe diabetes, showed a similar metabolic behaviour, i. e. all the rats decreased their blood glucose levels below $180 \mathrm{mg} / 100 \mathrm{ml}$ after an additional 8 months (data not shown). This makes it unlikely that the relatively short period of severe diabetes (11 days) before the LC-HP diet was given could play a role in the improvement of the diabetic state.

The triglyceride levels (Fig. 4) from the fifth week onwards were approximately proportional to the fat content of the diets (Tab. 1), results that agree with the findings of others [3] that chronically diabetic rats demonstrated only moderately increased triglyceride levels when fed on a normal diet and very high levels on a fat-rich diet [3]. The lack of rise in free fatty acids in the blood of the diabetic controls agrees with the findings of some authors $[3,23,24]$. The reason why a marked rise was found by other groups $[25,26]$ could perhaps be explained by the fact that their determination of free fatty acids was performed 2-3 days after the injection of the diabetogenic agent. At this time the diabetes is acutely decompensated and only after about 4 weeks is it more or less stable. This stabilization has been explained by a general adjustment of the metabolism [3] and by exhaustion of the lipid depots [23]. The latter hypothesis is supported by the finding that in chronically diabetic rats the free-fatty acids in the fasting condition tend to fall [3]. The low fatty acid level probably also explains the low ketone body levels in the diabetic controls [27] and the lack of ketonuria. The remaining plasma insulin levels in diabetic rats, although being clearly decreased, may have contributed to keeping ketogenesis at a low level [27]. The initially unstable diabetes may also be the reason for the initial marked hypertriglyceridaemia (Fig. 4) and ketonuria in the animals treated with the high protein diet.

The fact that a marked increase of cholesterol was found only in rats on the LC-HP diet is difficult to explain. Kritschevsky [28] pointed out that the content of raw fibre (with the exception of cellulose) appears to be of considerable importance for the binding and excretion of bile acids in the intestine. The protein-rich food contained, apart from cellulose, only a low proportion of raw fibre. The faeces of the animals fed with the protein-rich diet also contained scarcely any bile pigments; it was acholic and yellow, so that, possibly, the elimination of bile pigments was deranged and thus the excretion of cholesterol. An increased synthesis of cholesterol is unlikely, as this appears to be reduced in streptozotocin diabetic rats [29].

The data on lipid metabolism together with the excretion of urea give an indication of the type of energy metabolism of the animals. The LC-HP rats appeared to meet their glucose requirements predominantly from gluconeogenesis. This finding is supported by the fact that only these animals had a markedly raised urinary urea excretion and the fact that, except near the end, the excretion of glucose exceeded the daily carbohydrate intake, as can easily be calculated from Table 2 . In addition, these animals probably utilized more amino acids by deamination and oxidation of the carbon skeletons, which could also explain the increased excretion of urea. In the LC-HF animals the energy requirements appear to be met predominantly from the breakdown of fats. The markedly raised fatty acid and 3-hydroxybutyrate levels in blood and the relatively high ketonuria support this hypothesis. It is most likely that the muscles, heart and probably also the brain cells [30] of these animals had met a good part of their energy requirements by consumption of 3-hydroxybutyrate and acetoacetate.

Resistance to infection in the protein-rich diet group appeared to be somewhat reduced. In addition, the death rate in this group ( 6 out of 20 animals) was higher than that of the other groups, but is should be remembered that these animals were over one year of age. The total death rate, 7 of 59 diabetic animals, is low. Tumours of the kidneys were involved on two occasions. After sacrifice of the remaining animals two further renal tumours were found. It is well known that streptozotocin has carcinogenic effects [3] and may cause renal tumours [31], the kidney being a site where high concentrations of the drug are found [32]. The appearance of tumours in the nape of the neck, at the site of injection, may also indicate a carcinogenic effect of streptozotocin. It cannot be established from this study whether the higher death rate and the increased symptoms of infection had occurred by chance or whether they reflect a finding specific to the LC-HP diet. It should be noted, however, that in a subsequent long-term study [20] diabetic rats on this diet did not show an increased mortality or rate of infection.

This study has thus demonstrated that in severely diabetic rats a marked long-term amelioration of the diabetic state can be achieved by low carbohydrate diets. Since a diet containing only $6 \%$ carbohydrate may be considered extreme, it is of interest to note that in diabetic rats a marked improvement over 1 year has also been demonstrated with a $27 \%$ carbohydrate diet [20]. Low carbohydrate diets have also been shown to have beneficial effects on some secondary complications in diabetic rats: on basement membrane thickening [5] on the rarification of endothelial and perimural cell nuclei in retina preparations $[33,34]$, on the development of cataracts [20], and on the impairment of motor nerve conduction velocity [35]. Although in humans improvement 
of the GTT in mildly diabetic patients has also been reported with high CHO diet [36], a clear amelioration of the metabolic situation has been shown with CHO restriction [e. g. 37], independent of weight loss. The results of the present study should encourage further investigation.

Acknowledgements. We are grateful to Miss K. v. Dahl, Mrs. M. Kief, Mrs. P. Heidrich, Mrs. M. Buttmi, Mrs. I. Herrmann, Mrs. L. Perry, Mrs. I. Gutschalk and Mrs. I. Klahm for technical assistance, to H. Gierschner for preparation of the food, R. Neudecker for statistical advice and Dr. R. Hooper for help in preparing the manuscript in English. We should also like to thank Drs. P. P. Studer and W. A. Müller, Institut de Biochimic Clinique, Geneva, Switzerland, for the determinations of insulin and glucagon.

\section{References}

1. Siegel E, Trapp V, Schmidt F H (1976) Response of parameters of carbohydrate and lipid metabolism in 10 month diabetic rats to extreme reduction of the carbohydrate supply in the food. Diabetologia 12: 419

2. Rerup C C (1970) Drugs producing diabetes through damage of the insulin secreting cells. Pharmacol Rev 22: 485-518

3. Rudas B (1972) Streptozotocin. Drug Res 22: 830-861

4. Rasch R (1979) Prevention of diabetic glomerulopathy in streptozotocin diabetic rats by insulin treatment. Diabetologia 16: $125-128$

5. Fox C, Darby S C, Ireland J T, Sönksen P H (1977) Blood glucose control and glomerular basement membrane thickening in experimental diabetes. Br Med J II: 605-607

6. Chlaralampous FC, Hegsted DM (1950) Effect of age and diet on development of cataracts in the diabetic rat. Am J Physiol 161: 540-544

7. Rodriguez R R, Krehl V A (1951) The influence of diet and insulin on the incidence of cataracts in diabetic rats. Yale J Biol Med 24: 103-108

8. Hilgenfeldt J, Papner B, Kattermann R, v Dahl K, Heidrich P, Schmidt F H (1977) Glucosebestimmung im Auto-Analyzer II mittels Hexokinase-Technik im Hämolysat. Med Lab (Stuttg) 30: $278-286$

9. Schmidt F H, Schmidt G, v Dahl K, Stork H (1972) Automation der enzymatischen Triglyceridbestimmung in Serumproben. J Clin Chem Clin Biochem 10: 160-163

10. Schmidt F H, v Dahl K (1978) Ketokörper in Serum und Harn. In: Englhardt A, Lommel H (eds) Methodische Fortschritte im medizinischen Laboratorium, Akute Syndrome, Band 3. Verlag Chemic, Weinheim, p 40-44

11. Fawcett J K, Scott J E (1960) A rapid and precise method for the determination of urea. J Clin Pathol 13: 156-159

12. Astrup P. Jørgensen K, Siggard-Andersen O, Engel K (1960) The acid-base metabolism. A new approach. Lancet I: 1035-1039

13. Watson D (1960) A simple method for the determination of serum cholesterol. Clin Chim Acta 5: 637-643

14. Eggstein M, Kreutz FM (1966) Eine neue Bestimmung der Neutralfette im Blutserum und Gewebe. Prinzip, Durchführung und Besprechung der Methode. Klin Wochenschr 44: 262-267

15. Duncombe W G (1964) The colorimetric micro-determination of non-esterified fatty acids in plasma. Clin Chim Acta 9: $122-125$

16. Herbert V, Lau K S, Gottlieb C W, Bleicher S J (1965) Coated charcoal immunoassay of insulin. J Clin Endocrinol Metab 25: $1375-1384$
17. Unger R H, Aguilar-Parada E, Muller W A, Eisentraut A M (1970) Studies on pancreatic alpha cell function in normal and diabetic subjects. J. clin. Invest. 49: 837-848

18. Sachs L (1969) Statistische Auswertungsmethoden. Springer, Berlin Heidelberg New York, p 293-314

19. Jung, S (1962) Grundlagen für die Zucht und Haltung der wichtigsten Versuchstiere. Gustav Fischer, Stuttgart, p 191-229

20. Siegel E, Trapp V, Hartig F, Schmidt F H (1977) On the prevention of severe streptozotocin diabetes in the rat by low carbohydrate diets (long-term study). Diabetologia 13: 432

21. Schubert GE, Schuster H P, Baum P (1964) Physiologische Glucosurie bei verschiedenen Diuresezuständen. Klin Wochenschr 42: 619-622

22. Junod A, Lambert A E, Stauffacher W, Renold A E (1969) Diabetogenic action of streptozotocin: relationship of dose to metabolic response. J Clin Invest 48: 2129-2139

23. Wieland O, Löffler G (1963) Über den Mechanismus der gesteigerten Ketonkörperbildung. Biochem Z 339: 204-211

24. Steiner H, Oelz O, Zahnd G, Froesch ER (1970) Studies on islet cell regeneration, hyperplasia and intrainsular cellular interrelations in long lasting streptozotocin diabetes in rats. Diabetologia 6: 558-564

25. Mansford K R L, Opie L (1968) Comparison of metabolic abnormalities in diabetes mellitus induced by streptozotocin or by alloxan. Lancet I: $670-671$

26. Willms B, Ben-Ami P, Söling HD (1970) Hepatic enzyme activities of glycolysis and gluconeogenesis in diabetes of man and laboratory animals. Horm Metab Res 2: 135-141

27. Felig P, Koivisto V (1979) Recent advances in body fuel metabolism. In: Freinkel N (ed) Contemporary metabolism, Vol. 1. Medical Book Company, New York, p 359-383

28. Kritchevsky D (1977) Dietary fiber and other dietary factors in hypercholesteremia. Am J Clin Nutr 30: 979-984

29. Dayen M N, Dubuc J, Dvornik D (1975) Effect of clofibrate on lipid metabolism in streptozotocin diabetic rats. Proc Soc Exp Biol Med 148: 752-757

30. Owen O E, Morgan A P, Kemp H G, Sullivan J M, Herrera M G, Cahill G F Jr (1967) Brain metabolism during fasting. J Clin Invest 46: 1589-1595

31. Arison R N, Feudale E L (1967) Induction of renal tumor by streptozotocin in rats. Nature 214: 1254-1255

32. Karunanayake E H, Hearse D J, Mellows G (1974) The synthesis of ${ }^{14} \mathrm{C}$-streptozotocin and its distribution and excretion in the rat. Biochem $\mathrm{J} 142: 673-683$

33. Studer P-P, Trapp V, Siegel E, Schmidt FH, Muller W A (1975) Alterations in retinal capillaries of chronically (12 months) diabetic rats. Diabetologia 11: 378

34. Trapp V, Siegel E, Studer P-P, Zroustova M, Peter S, Schmidt F H (1976) Long-term study of the effects of extremely low carbohydrate (LC) diets on diabetes-induced late changes in the lens, retina, nerve, and kidney of rats. Diabetologia 12: 423

35. Fox C, Lowy C, Wright N (1975) The effect of diabetic control on motor nerve conduction velocity. Diabetologia 11: 342

36. Anderson J W (1977) Effect of carbohydrate restriction and high carbohydrate diets on men with chemical diabetes. Am J Clin Nutr 30: 402-408

37. Perkins J R, West T E T, Sönksen P H, Lowy C, Iles C (1977) The effect of energy and carbohydrate restriction in patients with chronic diabetes mellitus. Diabetologia 13: 607-612

Received: August 31, 1978 ,

and in revised form: August 20, 1979

Dr. E. G. Siegel

Institut de Biochimie Clinique

Sentier de la Roseraie

$\mathrm{CH}-1211$ Geneva 4

Switzerland 